\title{
Indeevari DODANTENNA*
}

\section{Hope or Fear? A Contemporary Portrayal of Immigrants in British Regional Newspapers}

\begin{abstract}
How does the press represent immigrants? The leading scholarship in framing studies argues that immigrants are mostly represented negatively in the national press, which aligns with the dominant discourse. But does that negativity exist in the local newspapers too? Focusing on the immigration debate surrounding Brexit, the following study was set out to examine ten local newspapers from the most populous city regions in the UK during three snapshot time points from November 2018 to April 2019. The six-week period, which was mainly based on Brexit milestones, served as data collection points.

The evidence suggests that local press coverage largely portrays immigrants in a favourable manner, proving support and highlighting their need and contribution. The said positivity was closely followed by the threat frame which depicts sentiments of fear, panic, burden and hostility. However, a shift in the positive discourse, towards threat, was noted during the mid-time point that was mainly fuelled by the elite rhetoric. Among the findings, the Scottish open arms policy towards the immigrants is very significant. It is mainly linked to their local concerns, such as labour shortages and population decline. While the study contributes to the growing literature in local media research, it also highlights how domestic needs could push back on the dominant discourse.
\end{abstract}

Keywords: Local newspapers, framing, immigrants, UK

\section{Introduction}

As a salient issue, immigration has garnered much interest in the UK media in recent past. Its implications related to society and economy are considered as pressing concerns for the British public (Duffy \& Frere-Smith, 2014; Ford \& Goodwin, 2014), which played a significant role in recent elections and the referendum. The growing inflow of immigration also increased the quantity of the public who viewed it as a problem over the years (Page, 2009). As the post-referendum studies reveal 'immigration' and 'sovereignty' were the two main reasons behind the leave vote (Carl, 2018). Although immigration is not a mere British problem, opinion polls during recent elections and the 2016 referendum have placed it above oth-

\footnotetext{
* Newcastle University, UK, indeevari.dd@gmail.com
} 
er issues like the economy, health services, unemployment, and crime (Ipsos MORI, 2014). Media reports claim the above factors to be directly affected by immigration (Fox, 2018). British political party agendas and campaign promises, as well as the growth in popularity and public support for parties such as the UK Independent Party (UKIP) also reflect these concerns towards immigration.

Given its complexity, immigration cannot be understood through individual experiences (Lawlor, 2015). Therefore, the complexity of immigration allows media to provide narratives that would shape public's understanding of it. Hence, the media discourse is presented through certain viewpoints and stereotypical images to convey a specific interpretation of an event (Gerbner, 1969). Thus, taking framing theory as its theoretical framework, the following study was set out to examine the contemporary representations of immigrants, portrayed by the British regional newspapers via the frames they use. To achieve the above-mentioned objective, the research has reviewed newspapers of ten big city regions of the UK to explore current trends in the depiction of immigrants.

\subsection{British Immigration and Representation of Immigrants Over the Years}

The term immigration tends to cause mixed attitudes among individuals (Sobolewska, Galandini \& Lessard-Phillips, 2016). Although the general preference is for highly educated, skilled, culturally and linguistically similar immigrants, the European Union showed more support for their own EU nationals than the non-EU immigrants (Eurobarometer, 2016). However, British citizens did not hold much different opinions regarding the EU and the non-EU immigrants in the UK (Eurobarometer, 2016). Moreover, their concerns regarding immigration are not exclusive to the EU immigrants, but immigration as a whole (Fox, 2018). Nevertheless, reasons behind Brexit do recall UK's historic controversies regarding European integration, which also suggest a weak sense of European identity among British citizens (Carl, 2018).

Similar to many European nations, the UK's journey in becoming a country of immigration has been troubled and complicated. Multiculturalism was considered to be an "unwanted consequence of the desire to retain the British Empire at the end of Second World War" (McLaren \& Johnson, 2007, p. 710). Commonwealth citizenship status prior to 1962 immigration policy allowed free movement for both new and old commonwealth citizens to the UK. Although concerns for a growing number of immigrants from the West Indies since the end of Second World War resulted in 1958 in race riots, demanding to halt black migration - the politicians continued to maintain pseudo-open-door policies to retain the commonwealth linkage. However, these policies were mainly used to restrict coloured migration (Spencer, 2002).

The immigration act of 1962 hoped to halt new immigration to the country, which was already multiracial and diverse. As argued by Joppke (1999), British Immigration policy is based on conflicting ideas of race and commonwealth citizenship (birth and ancestry) that functioned as an ethnic marker to define Britishness. For instance, despite being neither citizens of the UK nor subjects of the Commonwealth, the Irish benefited from racialised preferences. As a result of the Immigration Acts of 1961 and 1962 policymakers attempted to restrict coloured migrants arriving from the Commonwealth while opening a backdoor to the Irish by exempting them from immigration control based on their shared whiteness (Paul, 1997). Evidence of such racial preference can be seen in a seminal study that examines the politics of immigration and media representation in Hartmann and Husband (1974), who used a con- 
tent analysis of four national newspapers (from 1963 and 1970) and a survey to explore white British attitudes towards non-white people. The period showed a rise in the newspaper coverage of articles that are related to race issues, with a prominent theme that raised the "question of keeping them out" while representing the non-white population as a "problem" or an "oddity" (Hartmann \& Husband,1974, p. 145). Similar to the previous study, several newspaper analyses throughout the decade have shown the relatively problematic reception, politicisation and racialisation of the immigration issue that was heightened by the arrival of Black and Asian migrants from Commonwealth countries during the 1970s (Hartmann \& Husband, 1974; Hartmann, Husband \& Clark, 1974).

Although the 1981 British Nationality Act revamped the idea of citizenship with a new category called UK citizen with more official acceptance of diverse immigrants, the British public was not in favour of welcoming migrants but of restrictions to limit the numbers (Joppke, 1999). Over the years, British public perception about immigration has been fluctuating. Although more than $90 \%$ of British public hoped for restrictive immigration policies, over the years public opposition declined to approximately $65 \%$ in 1995 , then once again gradually rising since the 2000s (McLaren \& Johnson, 2007). Evidence suggests that more hostile public perceptions are grounded in the idea that immigrants take advantage of economic resources while being "symbolic threats to the British way of life" (McLaren \& Johnson, 2007, p. 709). Effects of public opinion could be again seen in the much recent past when immigrant numbers were restricted with a set target for annual net immigration (UKBA, 2011a). According to the UK government, the above immigration restrictions were enforced as a direct response to public perceptions regarding immigration (UKBA, 2011b). Therefore, one of the UK's most significant struggles in the recent decades up to the 2000s has been between its support of multiculturalism and the lack of policies that promote diversity to combat xenophobia and hostility. However, after 2005 the composition of the new immigrants changed from solely being from the Commonwealth to coming from other regions of the world such as Africa, East and South-East Asia, Middle East and most prominently Eastern Europe (Spencer, 2002).

The starting point of this phase may correspond with the European Union's most significant enlargement so far (i.e., May 2004) when eight Eastern European countries (EU8) joined the EU, followed by another two nations- Romania and Bulgaria in 2007. Soon, Eastern Europe became the largest source region of immigrants to the UK, contributing to the formation of one of the largest foreign-born populations in the country (McCollum \& Findlay, 2011). By the end of 2015, UK's net migration rose to a recorded high at 336,000 while intensifying public concern (Clarke, Goodwin \& Whitley, 2017).

Migration debate was intensified during 2013 in the British press - especially in the tabloids such as Daily Mail and Daily Express (Cheregi, 2015). Immigration-related claims made by political leaders also increased the salience of immigration between the latter half of the 1990s and through the first half of the 2000s (Carvalho, Eatwell \& Wunderlich, 2015).

After the financial crisis in 2008, the inflow of cheaper European labour helped to restructure the existing labour forces (Cheregi, 2015). Meanwhile, European identity among the British public was subject to a decline, while British nationalistic sentiment was constantly growing (Ormstone, 2015). This social transformation, which was visible in the resurgence of populism in the aftermath of the Brexit vote actually renewed the idealisation of a heartland as its core value (Corbett, 2016). Opposition towards immigration was used as one of the most effective measures to protect British values and norms. 
By 2015, the gradual increase in immigrant numbers over the years has transformed immigration to be one of the most salient issues in the current British society (Clarke, Goodwin $\&$ Whitley, 2017). This was clearly reflected through the public opinion poll at the end of 2015 with $63 \%$ placing immigration above other vital concerns such as healthcare (39\%) or economy (33\%) (YouGov, 2015). Notably, the view that immigration numbers are too high, was particularly strong among the pensioners and the working class - two groups who played a crucial role in deciding the outcome of the referendum (Clarke, Goodwin \& Whitley, 2017). Therefore, UK's inability as a part of the EU to regulate immigration flows from the enlarged $\mathrm{EU}$, which is inevitably linked to the freedom of movement of workers principle was considered to be one of the reasons behind the victory of the leave vote (Ipsos MORI, 2016).

Growing public concern is also reflected through the British political party agendas and campaign promises, as well as the growth in popularity and public support for parties such as the UK Independent Party (UKIP). Views such as the immigrants being 'British job stealers' were pushed by UKIP and its party leader, Nigel Farage (Clarke, Goodwin \& Whitley, 2017). Simultaneously, the public perception regarding immigration was heightened with the refugee crisis taking place in Europe sparking sympathy at their plight as well as intensifying anxiety at the difficulty in securing borders and the threat of terrorism. These anxieties were also grounded with incidents such as Paris terrorist attacks and Cologne New Year's assaults by refugees (Clarke, Goodwin \& Whitley, 2017). These issues were then used as a rhetoric to sway the public opinion by populist parties such as the UKIP.

"We know how bad our government is at defending our borders, and within a few years, all of these people (Middle Eastern Refugees) will have EU passports. We are much less safe as a part of this European Union" - Nigel Farage (BBC 2016).

Although the far right often uses the anti-immigrant rhetoric at the centre of their politics, the terrorist attacks and immigrant issues in Europe also seem to change the mainstream political debate on migration significantly to the right with mainstream national political leaders using inflammatory language in reference to immigrants and asylum seekers (Clarke, Goodwin \& Whitley, 2017). Then Home Secretary David Blunkett came under fire for referring to child asylum seekers for 'swamping' some British schools (BBC News, 2002) while former Prime Minister David Cameron was criticised for describing migrants seeking to reach Britain as 'swarms of people coming across the Mediterranean' (BBC News, 2015). Even after the referendum vote Theresa May's rhetoric of 'immigration could make society less cohesive' and "If you believe you are a citizen of the world, you are a citizen of nowhere" has added more spark to the negative and hostile nature of the anti-immigration rhetoric in the UK (Moore, 2016).

"Should the United Kingdom remain a member of the European Union or leave the European Union?" was the question that resulted with one of the highest voter turnouts at $72.2 \%$ (The Electoral Commission, 2016). The outcome changed the direction of the country, leading the current British government to formally put an end to the 43-year membership of the 'European Project'. Therefore, the significance of the role of immigration in Brexit is undeniable. Given the nature of the process and governmental efforts to deliver Brexit, it could be predicted that the UK's exclusion from 'the freedom of movement' will restrict migration influxes. Further, the evidence also clearly shows that attitudes and opinions towards immigration and immigration policymaking have always been the most salient issues that created a need for the referendum prompting Britain to leave the EU. 
It should also be noted that contrary to popular belief and high political salience, migration is not consensually understood in the UK (Blinder \& Allen, 2016). In addition to being a complex matter, the immigrants consist of varied types (Moses, 2006). Among those different types, the British public seems to recognise asylum seekers as the 'prototypical immigrant' to the UK (Blinder \& Allen, 2016, p. 5). Scholars also claim that public opposition is mainly felt strongly towards illegal migrants and asylum seekers (Blinder \& Allen, 2016) while negative media coverage of migrants invoke negative sentiments among the British public (Balch \& Balabanova, 2016; Threadgold, 2009).

Overall, immigration-related concerns of the British public are of complex nature which cannot be boiled into a binary choice of a referendum (Dennison \& Geddes, 2018). Similarly, other researchers also note the nuanced and complex nature of perceptions among British public, arguing that people are less eager to reduce the number of immigrants who are highly educated, skilled, paying for education institutes or investing in the UK (Crawley, McMahon \& Jones, 2016). Further, they are more likely to view immigrants from certain nationalities such as German, Australian or Indian as more positive contributors to the country and economy than Nigerians or Romanians (Crawley, McMahon \& Jones, 2016). However, such public perceptions are considered by scholars to be prejudices that could be far from the true nature and impact of immigration (Crawley, McMahon \& Jones, 2016).

\section{News Framing}

Framing is firmly attached to agenda-setting and priming, which together theorize the role of media in influencing public perception. In political debate, frames are used as tools to provide meaning to issues which is crucial for building arguments (Crawley, McMahon \& Jones, 2016). Media framing matters to public perceptions of policy, in areas such as immigration where people often lack personal experience (Lawlor, 2015). While framing is considered a process, it also defines and constructs a political issue or public controversy. Entman (1993) notes that frames are encoded in specific phrases journalists use. The acceptance of such frames would then result in social acceptance. Further, as politics are multifaceted, frames could provide different ways to think about it (Valentino \& Nardis, 2013).

Framing theory lacks a precise definition (Druckman, 2001; Sniderman \& Theriault, 2004). However, over the years, there have been several attempts at defining framing. Among the earliest definitions is that of Goffman (1974) who identifies and defines the characteristics and the functioning of frames in society as a "a central part of a culture" which is "institutionalized in various ways" (p.63), while individuals use a "schemata of interpretation" or frameworks to brand or label events (p. 21). Thus, individuals interpret events based on the contexts. Meanwhile, Entman (1993) defines framing as a concept that focuses on the selection and prominence as the main attributes of news stories.

"To frame is to select some aspects of a perceived reality and make them more salient in communicating text, in such a way as to promote a particular problem definition, causal interpretation, moral evaluation, and/or treatment recommendation for the item described" (p. 52).

Entman (1993) also notes that framing chooses "some aspects of a perceived reality and make them more salient in communicating text, to promote a particular problem" (p. 52). For instance, Fox (2018) notes that the fears about catastrophic consequences of the increase in 
immigration numbers are "incorrect and have no academic grounds" (Fox, 2018, p.14) Further, "the news media's anti-immigration discourse" has created a negative mindset and "a distorted perspective on immigration's impact" (Fox, 2018, p.14). The said 'negative mindset' relates to the valence of a frame, the tonality or the emphasis of a positive or negative aspects of a news story, which could decide the public support or rejection regarding an issue (de Vreese \& Boomgaarden, 2003).

Although a frame could be referred to the way "speakers and writers construct arguments about topics" the act of framing creates a link between those topics which results in a "value-judgements about its implications and impact on society" (Crawley, McMahon \& Jones, 2016, p.4). Similarly, Lecheler and de Vreese (2012) note that journalists' use specific news frame to have an influence on the importance of the news as well as the perceptions of the reader. However, according to Chong and Druckman (2007), it is the "process by which people develop a particular conceptualization of an issue or reorient their thinking about an issue" (p.104).

Taking another viewpoint, Iyengar (1991) claims that framing is a dynamic, context-bound process of opinion formation where dominant modes of elite rhetoric and media coverage form public opinion. In another definition, de Vreese (2005) describes framing as a process, where frames can be identified as "patterns of interpretation that are used to classify information" (de Vreese, 2011). Further, he notes that communication is "a dynamic process that involves frame-building or how frames emerge, and frame-setting, which could be understood as the interplay between 'media frames and audience predispositions' (de Vreese, 2005).

The catch-all term framing does not highlight the distinctions or the typologies in framing. Taking a deductive approach, issue- specific frames refer to a specific topic or an event that permits for an examination of the framing of a certain event in detail (de Vreese, Peter $\&$ Semetko, 2001). Therefore, it could capture the selection, organization, and elaboration in the news (de Vreese, Peter \& Semetko, 2001). Generic frames, on the other hand, provide evaluation across topics and frames, while surpassing issue, time, and space limits (de Vreese, Peter \& Semetko, 2001). Nisbet, Broussard and Kroepsch (2003) claim that generic frames dominate the general news with frames relating to conflict, ethics or morality.

Another critical aspect in framing relates it to the traditions of thinking in sociology and psychology, where the basis for the two different framing types - equivalence and emphasis frame derive from. Equivalence framing that stems from psychological approach, manipulates the "presentation of logically equivalent information" (Scheufele \& Iyengar, 2012). The same news story or information is subjected to different modes of presentations, making the interpretation of information dependent on the context or the frame. The presentation of information, therefore, could be framed either as a benefit or a cost (Kahneman \& Tversky, 1979). Another way of establishing a frame of reference is based on emphasis framing, which is drawn from sociological concepts. Emphasis framing tends to omit of information purposefully, which is related to the topic or news story that may "purvey a set of judgements about it" (Entman, 1993).

While equivalency framing often display valence, it could be seen in emphasis framing too. De Vreese and Lecheler (2012) state that valence can be applied to emphasis framing, as seen in elite political discourse where deliberate attempts are made to "support or reject an issue by connecting positive or negative aspects of it with different sets of considerations"(p.296). With regards to immigrant frames, Blinder and Jeannet (2018, p. 
1446) suggest that "frames can influence public opinion by contributing to this process of shaping political cognition, which essential prerequisites for holding political attitudes".

\section{Immigration Frames in the British Press}

Immigration is a matter of controversy in the UK. However, it is not a mere British issue as studies in other countries also state that immigrants are framed in a negative manner in the media. The threat or problem frame dominates most of the press portrayals, closely followed by 'moral panic', othering, crisis, and racialization frames. For instance, referring to then-presidential nominee Donald Trump's criticism of male Latino immigrants as 'bad hombres', Mohamed and Farris (2019) argue that the US press over-represented male Latino immigrant above other immigrants to the country while depicting them as a threat. In a similar gendered and racialised association, the Israeli media depicted the Russian female immigrants in a negative light, mainly as sex workers and then as the 'other' who is not a part of 'us' (Lemish, 2000). Breen, Haynes and Devereux (2006) argue that negative media coverage creates fear about new immigrants in Irish society. Even in countries renowned for acceptance of migrants and asylum seekers such as Canada, the print media discourse provided emphasis as the immigrants were significantly framed as a threat to the security as well as taking advantage of social benefits (Lawlor \& Tolley, 2017). Similarly, a European Commission's report in 2006 states that among a variety of perceptions towards migration, "overall public attitudes have been mostly negative throughout Europe" (Beutin et al., 2006, p. 2). European Commission reports of 2011 and 2014 note that negative press coverage about migrants results in stereotyping the migrants in a negative manner.

Similar to that of other countries, the body of research related to UK's media representations shows the recurrence of a few key themes that have resulted in an ambivalent representation of migrant groups, mainly invoking negativity. The frames project the migrant groups as innocent 'victims' in a destitute state, simultaneously projecting them as invading 'villains' who pose an imminent 'threat' to Britain and its citizens (Balch \& Balabanova, 2016; Berry, Garcia-Blanco \& Moore, 2015; Crawley, McMahon \& Jones, 2016). The dominant 'threat frame' refers to the security threat rhetoric (Huysmans \& Buonfino, 2008) and disaster narratives (Charteris-Black, 2006). Such negative framing has been reported even in early studies where migrants were depicted similarly as a problem or a threat (Hartmann \& Husband, 1974). Thus, a reasonable consensus from literature justifies that the negativity and threat frames are dominant in British newspapers' depiction of migrant groups.

Between 1999 and 2009, when the largest European Union enlargement took place which opened the British border to eight Eastern European nations, the political debate surrounding migration framed it as an 'invasion' (Light \& Young, 2009). The press rhetoric which focused on the numbers and statistics implied a burden that could strain the already scarce public resources (Threadgold, 2009). McLaren and Johnson (2007) note that these threats are identified as "threats to ingroup resources posed by immigration, threats to the shared customs and traditions of British society" (p. 709). According to news reports, these threat frames about war, drugs, crime or terrorism often unconsciously collocate the idea of 'foreign threats (Threadgold, 2009). Therefore, such verbalisation of different migrant groups as 'intruders' or 'invaders' also construct a sense of a crisis or war (Van Gorp, 2005), which could transform a social issue into a moral panic (Cohen, 1980). According to Gabrielatos and Baker 
(2008), the so-called moral panic "has increasingly become the dominant discourse in the UK press" which is mainly constructed by the British conservative and tabloid press (p. 33). Morrison (2019) notes that these fears could be mainly categorised into two groups. One based on classic moral issues around crime, public disorder and terrorism (Poole \& Richardson, 2006) while the other fears are based on job opportunities, public services and the welfare state (Balch \& Balabanova, 2016; Philo, Briant \& Donald 2018). Explaining the moral panic frame Cohen (1980) states that it is depicted as "a condition, episode, person or group of persons" that "become defined as a threat to societal values and interests; its nature is presented in a stylised and stereotypical fashion by the mass media" (p. 9).

The negative portrayal of migrant groups as a threat also rings at the growing scholarship on the securitisation of migration (Bourbeau, 2011; Huysmans, 2008). The political construction of migration has been responsible for warning about the 'destabilising effects of migration' on domestic societies (Huysmans, 2008). Thus, as argued by Huysman (2000), perceiving migration as a threat to the national communities would label the immigrants as a burden. The destabilising effect of migration on domestic integration was later mirrored through the development of a restrictive European migration policy, which gradually transformed migration into a security question (Huysman, 2000). As a result, migration and its related issues became key topics of contemporary security politics in Europe (Leonard, 2010). Thus, this trend was later referred to as the 'securitisation of migration' which reflected the extreme politicisation of migration and its presentation as a security threat (Leonard, 2010).

Evidence suggests that "news coverage focuses on conspicuous incidents and sensational conflicts" about immigrants that omits any information related to their daily lives thereby contributing to a negative image (d'Haenens \& de Lange, 2001, p. 849). Similar evidence could be found in the use of images of both right and left-leaning British press emphasising on fear, danger and risk with the portrayal of men climbing fences, approaching the tunnel or fighting with the police rather than pictures of their everyday lives (Buchanan, Grillo \& Threadgold, 2004). For instance, UK newspapers were called the "the most negative, and the most polarised," especially with right-wing media displaying heightened levels of hostility, during the European refugee crisis (Berry, Garcia-Blanco, \& Moore, 2015, p. 1). The predominance of negative frames was not just limited to news stories but was seen in the editorials, too (Berry, Garcia-Blanco \& Moore, 2015). According to Innes (2010), such demonstrations of negativity highlights the "irony of immigration discourse in advanced industrialised states where insecure are constructed as a threat" (p. 456). She further adds that the UK is a prime example of such a state where "individual human insecurity is seen as threatening a sovereign state"; therefore, the state security concerns "take precedence over individualistic concern for human rights" (Innes, 2010, p. 456).

The crime frame could be viewed as an extension of the threat frame or a frame on its own. According to Fox, Moroșanu \& Szilassy (2012) "crime frame suggests a tight, even inherent link between migrant and criminal" (p. 687). For instance, even before arriving in the UK, Romanians were described by the British press as 'illegal migrants' who are entering the country via illegal means, with evil intentions (Fox, Moroșanu \& Szilassy, 2012). After their arrival, their evil intentions were revealed through the crimes the varied crimes they were associated with, such as cashpoint and credit card theft, child trafficking, begging, and prostitution (Fox, Moroşanu \& Szilassy, 2012). Such repeated portrayal of Eastern European migrants as criminals project them as social parasites with moral deficiencies - thereby de- 
scribing criminality as an innate characteristic of the immigrants (Fox, Moroșanu \& Szilassy, 2012). Such depictions discriminate the immigrant groups while racializing them too.

The victimization of migrant bodies brings out the human interest frame that focuses on a personalised or emotionalised perspective on unfolding events (Steimel, 2010). Nevertheless, such portrayal could also be discriminative to a larger extent, especially if asylum seekers are depicted as desperate sufferers who are completely dependent on external support (Chouliaraki \& Zaborowski, 2017). Similarly, Crawley, McMahon and Jones (2016) point out that victimisation frames include humanitarian and integration frames that also position migrant as passive sufferers and the needy. However, Benson (2014) sees the victimisation frame in a sympathetic manner. Further, Crawley, McMahon and Jones (2016) note that most newspaper coverages are mainly one-sided with very little space provided for migrants to voice their perspective. Such portrayal contributes to their dehumanisation and the tendency to view 'them' as one large and threatening force. In a similar examination of asylum seekers, Innes $(2010$,) states that the UK press "constructs them as a homogeneous collective that threatens state interests" (p. 456). As a threat, they mainly raise concerns for being a traditional security threat, an economic threat and a societal identity threat (Innes, 2010). Moreover, the language that is used in asylum-seekers' context tends to be ambiguous and vague, omitting agency and responsibility; further dehumanising them (D'Haenens \& de Lange, 2001). This also echoes that the power of framing is in the way it operates by 'selecting and highlighting some features of reality while omitting others' (Entman, 1993, p. 53). Moreover, KhosraviNik, Wodak and Krzy ¿anowski (2012) also note that such constructions of migrant groups contribute to the 'panic' and 'othering' through the binary of 'us' and 'them'.

In their examination of the construction of migrants Crawley, McMahon and Jones (2016) state that migrants are mainly portrayed through victim (victims of inequality and/or discrimination), benefit (contribution of the migrant to the host society) and villain frames (a threat to security and the job). Evidence suggests the above can be linked to the 'securitisation' and 'economisation' discourses which is increasing in the public discourse (Caviedes, 2015) which projects migration in the light of security or the economy. According to Smith and Deacon (2018, p. 4), such projections place migration as "conditional on the costs and benefits" associated with these aspects. A similar transactional view of migration control, based on the relative costs and benefits calculation and the economy or the welfare state that weigh the impact of migrants on British workforce, schools and housing also echo the economisation frame (Balabanova \& Balch, 2010). The previously exposed factors also play a role into the racialization of migrant groups, which goes beyond the non-white groups. In their comparative analysis of tabloid and immigration policy Fox, Moroşanu and Szilassy, (2012,) argue that tabloid journalism "features institutionalised racism that implicitly invokes shared whiteness as a basis of racialised inclusion" towards Eastern Europeans immigrant groups (p. 680). Tabloids specifically invoke "cultural difference as a basis of racialised exclusion" while revealing the different degrees of whiteness that "gives 'race' its currency" (Fox, Moroșanu \& Szilassy, 2012, p. 680). Thus, negative frames feed into negative stereotypes about immigrants while creating an urgency (Segelola, 2018).

The negative portrayal of migrant groups could be further seen in the language used in migration coverage. Blinder and Allen (2016) together with Gabrielators and Baker (2008) note that most common portrayal of immigrants and asylum seeker as illegal migrants, failed asylum seekers and illegal refugees casts a negative light on these groups. Further, these groups are also represented in water or fluid terms to signify the scale of immigrants as a 'flooding, 
pouring, streaming' or 'wave', 'flood' or 'flock' (Charteris-Black, 2006; Gabrielators \& Baker, 2008; Vicol \& Allen, 2014). Such pejorative metaphor terms that are most related to disasters invoke the threat frames. Further such words remind of massive numbers that cite fear. Another negative term commonly used in collocation with these groups is 'crime'. Vicol and Allen (2014) found that tabloid newspapers often depicted Romanian migrants in relation to crime and anti-social behaviour, by using terms such as 'gang', 'criminal', 'beggar', 'thief', or 'squatter'. Furthermore, both Romanians and Bulgarians migrants were frequently associated with terms that are used to prevent movement such as 'stop', 'control', 'block' by tabloids and 'deter', 'restrict' or 'dissuade' by broadsheets (Vicol \& Allen, 2014).

Exploring a gendered and racialised perspectives of media narratives, Gray and Frank (2019) argue regardless of gender differences, both refugee men and women are depicted in a negative light. While women are perceived through a vulnerability lens that both racializes and feminises them; men are racialized and masculinised as a threat (Gray \& Franck, 2019, p. 287). Eventually, both "male and female refugees are made unsafe" (Gray \& Franck, 2019, p. 287). However, there seems to be a lack of pictures of refugee women, in contrast to the frequency of stock images of male asylum seekers with their faces partially covered, symbolising a break-in or an invasion (Buchanan, Grillo \& Threadgold, 2004). Similar evidence from other semiotic framing mediums also suggest further dehumanising depictions of migrant groups as threatening and exploitative of others (Philo, Briant \& Donald 2018).

Immigrant representation of the regional press also reveals a variety of frames, which, to a certain extent, follows the national presses' negative immigrant representations as a 'threat'. According to Rasinger (2010) migrants were depicted as actors of negative processes via themes of negative denotations and connotations while expressing the message that "migration is a danger that needs to be stopped" (Rasinger, 2010, p.1028). Similarly, Walter (2019) reports a variance of stance among national and regional newspapers stating that negative news articles about European citizens are more likely to appear in regional rather than national newspapers. Among the four countries that constitute the United Kingdom, regional newspapers from England and Wales were more likely to mention EU citizens if the tone of a news story was more negative (Walter, 2019). In a similar examination of Scottish newspapers, Catto, Gorman and Higgins (2010) analyse how the impact of Central and Eastern European immigration on health services in Scotland has been portrayed. The study indicates that the portrayal of migrants posing a threat to the National Health Services (NHS) has increased in frequency but changed in nature over the past four years (1st January 2004 to 1st April 2008). An interesting finding of the study is that those representations of threat in the Scottish press were closely followed by themes of reassurances (such as Scottish socio-economic conditions) to allay societies' fears. Finney and Robinson's (2008) examination of local press in Leeds and Cardiff find contradictory frames; some of which are consistent with that in the general negative representations, while others are based on frames of inclusion and accommodation of asylum seekers in the area.

\section{Data Collection}

Recent studies that have examined immigrant in the media have mostly done so cross-nationally (Gray \& Frank, 2019, Crawley, McMahon \& Jones, 2016) or by combining both national and regional media together (Walter, 2019; Lawlor, 2015). Meanwhile, some studies 
have focused on a single local area and have analysed them in an in-depth manner (Catto, Gurman \& Higgins, 2010; Finney \& Robinson, 2008). Those that have examined the local context note that "variability in incorporation of immigrants often exists at the sub-state level" (Lawlor, 2015, p. 920). Although national media is useful in understanding international trade or national security, immigration holds a distinctly local component as immigrants settle in cities and towns (Lawlor, 2015). Thus, the local newspapers might reflect a more insightful and uniquely local perspective that could be missing from the national media conversion; given that immigration attract urbanisation, employment opportunities and multicultural environments (Tuli, 2019).

For the data collection, following most populous city regions of (in ascending order), Greater London, West Midlands, Great Manchester, West Yorkshire, North East, Glasgow, Liverpool, Cardiff, Sheffield and Edinburg (Office for National Statistics, 2016) were selected. Based on the highest circulation numbers (ABC, 2018) of each city region following ten newspapers were selected; which are, Evening standard (Greater London), Express and Star (West Midlands), Manchester Evening News (Great Manchester), Liverpool Echo (Liverpool), The Herald (Glasgow), Yorkshire Evening Post (West Yorkshire) Yorkshire Post (Sheffield), Journal and Chronicle (North East), The Scotsman (Edinburgh), and South Wales Echo (Cardiff). LexisNexis database was used to gather the articles from eight newspapers except for Express and Star and The Star - Sheffield, which are not archived in the database. While, Express and Star was searched separately on its website itself, website of The Star did not allow any archival searches. Since the next most circulated newspapers of the Sheffield area were also not available in LexisNexis, Yorkshire Post, which covers the entire region of Yorkshire was then selected.

The study focuses on three-time points between November 2018 and April 2019. The first two points 14th -28th November and 15th -29th January are based on Brexit political significance. The first data collection point followed 14th November 2018 when Brexit withdrawal agreement was published. The second point on 15th January is when Prime Minister May's Brexit deal was defeated by a large majority of 230 votes. Although the third time point, which is from 29th March to 12th April included the most anticipated date in Brexit calendar; the postponement of the official leave date rendered it not so significant. Therefore, it was selected as an ordinary time point, with the expectation that the above date will provide an understanding of how the immigration debate of Brexit is conducted during general circumstances.

Subsequent to defining the time frames, previous studies were explored to examine possible keywords. Literature suggests several key terms that have been used by researchers when collecting the corpus. For instance, Crawley, McMahon and Jones (2016) note that broad search words such as immigration or immigrant were used to examine dominant frames regarding migrants in British national media. Allen and Blinder (2016) used keywords such as 'asylum', 'deport', 'emigration', 'illegal alien', 'immigrant', 'migrant', and 'refugee'. While examining Bulgarians and Romanians in the British national press, Vicol and Allen (2013) used collocations such as 'migrant worker' or 'immigrant worker' with the use of other words such as citizen, national, student and economic; which could also provide other collocative combinations of phrases to gather the news articles. Based on keywords used in the literature and common word used in the selected newspapers, a pilot study was carried out to decide on the keywords that would guide the selection of the relevant corpus of news articles. It was noted that keywords such as 'alien', 'emigration' or 'migration' did not help to 
gather specific articles for the corpus. After the pilot study, terms such as 'migration' was purposefully excluded as it tends to retrieve material related to biology, technology and environment among other areas (e.g., cell migration, data migration). Further literature also suggests that selected keywords are used in media as equivalent terms that "potentially inform readers understanding of immigrants and immigration issues facing Britain (Blinder \& Allen, 2016, p. 2). Based on the literature and the result of the pilot study; following query string was used to gather the data - migrant* OR immigr* OR refugee* OR asylum*. Some words were truncated to find related words that started with those first letters.

Following the data collection from the above mentioned ten newspapers on the three different periods, the data was cleaned for consistency prior to the analysis. Articles that mentioned immigrants in passing and all repetitive articles were removed from the sample. Then, the data was entered into the NVivo data management programme. Thereafter a frame analysis, that included a comprehensive process of data coding and identification of themes was undertaken. Findings of the analysis and the significance of the frames are discussed below.

\subsection{Key Frames During the Three Time Points}

The data analysis of the press portrayal of regional migrant groups in Britain during the Brexit process produced a total of 608 articles after its keyword search. However, after cleaning the data and checking the materials for relevance to immigrants and their related issues and removing repeated ones, the articles were limited to a corpus of 187. Overall, Express and Star published most number of articles related to immigrants at $20.7 \%$, closely followed by the Evening Standard and The Herald. Out of all articles, 53.2\% was contributed by the above three newspapers. The least number of articles at 3.25\% were published by the Yorkshire evening post. During the November two-week time period Evening Standard published most articles (27.7\%), followed by Express and Star (19.8\%). However, during January most articles were contributed by Express and Star (22.78\%). Overall, most threat frames (39\%) were present in Express and Star articles while most articles from Evening Standard were framed in the humanitarian frame at $30 \%$. The coverage also demonstrates that immigration intersects a wide range of concerns and policy areas as the articles varied between Brexit, border security, referendum, EU free movement, US migrant issues, healthcare, economy, European migration issues, housing, employment, migrant detention, deportation and education among many other issues.

The first aim of this study is to identify the key thematic frames that appear in the press coverage of ten regional newspapers during the three time points. Six themes emerged as distinct frames from the data analysis that mainly provides negative denotations and connotations. They are namely, (1) humanitarian, (2) threat, (3) victim, (4) economization (5) political contention and (6) migrant voices.

The Withdrawal Agreement and Political declaration commonly referred to as the Brexit deal was received with great opposition that had many members of the parliament calling for alternatives. The immigration plan of it was also met with similar viewpoints. These oppositions were heightened with Prime minister May's anti-immigration rhetoric of EU citizens as "queue jumpers" and criticism from a number of stakeholders including business leaders who referred to the migration plans as a "seismic shift" (Express and Star, 2018a). These concerns were also shared by the state sector too, as "NHS (National Health Services) feared the new system could cut off the supply of overseas nurses and carers" (Express and Star, 2018a). 
Meanwhile, the immigration plan contributes to the increase of EU citizens planning to return to their home countries, given the uncertainty of Brexit and support for them. Overall, the two-week time period in November with reference to immigration and immigrants was mainly marked by uncertainty, which could explain the dominance of humanitarian frame that reflected support towards the immigrants. A number of news reports referred to a large number of EU nationals (between 3 to 4 million) who were required to apply for settlement in the UK. During this period, the humanitarian frame was most used by newspapers such as Evening Standard (London), Express and Star (West Midlands), The Herald (Glasgow).

The threat frame which closely followed the humanitarian frame referred to the news stories of organised crime, illegal activities, immigration offences that involved migrants. Further, it also invoked the burden frame with lack of resources and funding to serve the growing number of asylum seekers and refugees. The negative representation of migrants was continued with the victim frame with stories of hostility, including 'waterboarding of a 15-year-old Syrian refugee' at a community school (Express and Star, 2018b). As divisive phenomena, both Brexit and immigration laws were reflected through the political contention frame, which also highlights the need to rise above political disagreement.

"It's crucial that this new system reflects the needs of our economy, rather than arbitrary political targets." (Murphy, 2018)

The time period in January marked by the defeat of the Brexit agreement was a period of high political salience. However, it also marks the passing of the new immigration bill that "ends EU law on free movement in the UK and placed European Economic Area (EEA) nationals and their families under UK immigration control after Brexit" (Holden, 2019)

The threat frame overtook the humanitarian frame during the period mainly with reference to incidents of the migrant crossing the English Channel that was received by the government as a security threat. The incident was previously labelled by the home secretary, Sajid Javid as a "major incident" while "questioning whether people risking their lives crossing the English Channel are "genuine refugees" (Express and Star, 2019a). Towards the latter part of January, the while a joint action plan with to guard the channel with French forces were revealed. While Immigration Minister Caroline Nokes pledged that "Britain will step up pressure to return migrants who have crossed the English Channel" (Liverpool Echo, 2019). Although there were several other incidents related to migrants invoked threat and fear, such rhetoric from elite groups as Home secretary and Immigration minister on several occasions contributed a considerable portion of the threat frame during this period.

Meanwhile, the humanitarian frame highlighted the concerns of EU nationals who must register for settlement for the post-Brexit scheme as the first public testing phase started off on 21st January. Among international news, migrant rescue missions in the countries such Italy and Turkey, the migrant crisis in the US border and Pope Francis's claims in central America condemning the adverse treatment of migrants as the 'fear of migrant' also contributed to the humanitarian frame during the time period.

Compared to that of the November period the political contention frame resulted in a smaller number of frames during the January two weeks. Similarly, economisation frame reported a drop during the January period.

The third time point from 29th March to 12th April which did not follow any particular incident of political salience was once again was dominated by the humanitarian frame. The political atmosphere in the country during the time was of disorder and division marked by 
uncertainty, with former Brexit deadline being postponed without the majority's agreement. The very nature of the change and uncertainty seemed to have given rise to most of the humanitarian frame that was of encouragement and support towards migrant groups with special reference to EU nationals. Several requests and pleas from elite political actors from both side of the political aisle encouraged European union citizens to continue their stay in the UK. For instance, the following request of immigration minister Caroline Nokes specially directed at the EU citizens living in Scotland seems to capture the tone and sentiments of most of those messages.

\footnotetext{
"There are more than 3.5 million EU citizens living in the UK, including over 180,000 people who have made their home in Scotland. They, like many others, have played a fundamental role in Scotland's cultural and economic prosperity by building communities around them, supporting Scotland's thriving industries and integrating into Scottish life. My message is clear - we want you to stay regardless of the UK's future relationship with the EU. You are our friends, family and neighbours. You have contributed so much to our society and our economy. That is why our first priority in the Brexit negotiations was to secure your rights." (Nokes, 2019)
}

While several articles from the examined newspapers of other city regions invoked such feelings, it was particularly noted that in the two Scottish newspapers in the data set, namely The Herald (Glasgow) and The Scotsman (Edinburgh). However, given that Scotland voted to remain in the 2016 Referendum, such sentiments towards European union nationals could be considered natural. Further, similar sentiments could relate to the economic benefits of migration that highlighted the need for European union labour for the economic development of Scotland.

"UK Government's immigration plans could cut workers in Scotland by up to 5 per cent in the next two decades." (Paterson, 2019)

One of the noted factors about the frames in March- April time point is a rise in migrant success stories frame, which exceeded the threat frame. While it celebrated their accomplishments and being successful in the UK, it even sensationalised some of them as 'rag to riches' stories. Further, another notable aspect is that most of the articles related to migrant success stories frame allowed the immigrants to express themselves and their experiences, giving an insight into the struggles of integration and other cultural barriers.

\section{Key Frames in the Regional Newspapers}

Generosity, hospitality and the general supportive nature of the British people, authorities, organisations and the government which called for a compassionate stance in the public discourse were found in articles that emphasised humanitarian frame (Crawley, McMahon \& Jones, 2016) in the examined newspapers. Most reports highlighted various aid work done by communities and charity organisations for the benefit of asylum seekers and refugees. Further, there were several calls to action to support and uplift the lives of those who live in conflict zones, such as petitioning to appeal to "Theresa May and other world leaders to increase funding to support the mental health and emotional needs of children affected by conflict". (Busby, 2018). However, it also highlighted the efforts by the governmental organisations such as the Newcastle city council who are a self-proclaimed "city of sanctuary" for immigrants and asylum seekers specially during politically divisive time as Brexit (Holland, 2019). 
The humanitarian frame also aims to support migrants by dismissing myths about them, while helping them to integrate to British society and highlighting the importance of diversity. It also extends to pro-immigrant dialogue that actively seeks justice for the immigrants in need and showcasing those who have faced issues for rescuing immigrants. Further, they also emphasise the instances where anti-immigrant narratives have been changed to support migrants in need. A clear example of that is Express and Star's (2018c) article with the headline "Italy's anti-migrant interior minister welcomes refugees escaping war". However, the pro-immigration stance towards the EU citizens was depicted through several articles that highlighted Brexit citizenship registration issues they had to face claiming it would surpass the notoriety of the Windrush scandal (South Wales Echo, 2019) As the most dominant frame, the humanitarian frame was quite effective in the examined context. Other than Evening Standard, the frame was quite evident in the two Scottish newspapers, The Herald and the Scotsman. Nevertheless, it did show prominent visibility in other newspapers too.

The threat frame is an amalgamation of several numbers of subframes, which mainly contributes to the fact that immigration is a threat to the UK and its people. It encompasses migration as a security concern; that it should be controlled or restricted, which also lead to the control frame; as well as a burden on the state and authorities. It is further displayed through the criminality and public safety frames too. Among the ten newspapers, Express and Star (West Midlands) and Manchester Evening News (Manchester) used threat frame as their dominant frame. Although rather prominent 'threat frame' is the second most recurrent frame among all identified frames. This finding differs from that of Crawley, McMahon and Jones (2016) who note that $46 \%$ of the articles from their study on British National press "framed migration as a threat or migrants as actual or potential villains" (p. 18) making it the most dominant frame. Similarly, a number of other studies have also argued that migrants are mainly depicted as a 'threat' in British newspapers (Balch \& Balabanova 2016; Berry, GarciaBlanco \& Moore, 2015).

Securitisation is a dominant subframe within the threat frame, which mainly shows how migration and migrants are transformed into a security concern. For instance, the incidents of migrants who are crossing the English Channel from Calais, France are often described by elite actors as a national security concern and a breach where military intervention is needed to "combat illegal migration".

"We've stepped-up our law enforcement response through the NCA and other agencies, and earlier this week I announced two Border Force cutters would be returning to the UK from abroad - with a navy vessel helping with our patrols in the interim." Sajid Javid (Express and Star, 2019b)

Further, the positioning of the situation as a "crisis" that "require immediate action" also creates urgency and contributes to a sense of panic or looming danger. Similarly, immigrants are also described as displaying "threatening behaviour" that add to the above danger as well as to the safety and welfare of the citizens.

The next frame, 'criminality' places migrants as those who are involved in illegal activities. They mostly describe immigrants' involvement in drug distribution, fraud, theft, and other activities which are against the law or which they are not permitted do. It was noted that most of the articles also refer to immigrants' unlawful activities in the past (Scott, 2019; Bridger, 2019). Further, in such instances, they are mostly described as 'illegal immigrants' and 'failed asylum seekers'. As agued by Fox, Moroșanu and Szilassy (2012) the crime frame suggests the existence of an "inherent link between migrant and criminal". Another subframe 
that contributes to the security frame is the public order frame where immigrants are depicted as a problem and threat to the safety of the British public that suggests them as a cause or root of an epidemic or a public health crisis.

"all immigrants from countries where TB is known to be should be tested/vaccinated before allowing them to come here. Too many diseases previously eradicated here are reappearing". (Manchester Evening News, 2018)

Moreover, the securitisation frame extends with the control frame that suggests that immigration is too high where stronger immigration control laws and policies are required. They mainly aim to restrict migration as a response to public concerns over the increasing numbers. Those concerns are also linked to the fact that immigration adds weight on the already scarce opportunities for employment, social benefits, increasing poverty and unemployment. Therefore, these issues deprive the British citizens of benefits they are entitled as the rightful owners of the land. These feelings are also often tied to the main factors that led to Brexit and reminded of the need and importance of fulfilling them without further delay. The Herald reports on Boris Johnson's call for action on immigration that will boost pay for British workers while accusing "big corporations of 'accessing unlimited pools' of foreign workers as one way to keep wages down for British Workers".

\footnotetext{
"Boris Johnson is calling for careful thinking on how to control immigration as he backs a wage boost for British workers and insists the Government should focus on the issues that drove Brexit." (Connolly, 2019)
}

Securitising of migration via the solidification of the 'in-group' identity against the 'outgroup' as above, "constructs political trust, loyalty and identity through the distribution of fear and an intensification of alienation" (Huysmans, 2006, p. 47). The debate about Brexit also brings forward the views and concerns of the pensioners and the working class who supported it (Clarke, Goodwin \& Whitley, 2017). As noted below, they still seem to hold the opinion that those who support immigration, especially the liberal elite, does not understand its detrimental effects, as they do not have to rely on welfare benefits.

"Old working-class communities bear the brunt of the negative effects of migrants, such as added pressure on housing, schooling, health and social services. It's the intransigence of the liberal elite that has made Europe more divisive and dangerous. As usual, it's the rich who gets the pleasure and the poor gets the blame." (South Wales Echo, 2018)

Such sentiments of this nature also ring at 'welfare chauvinism' described by Balch and Balabanova (2016) where "people believe that welfare benefits should be restricted to citizens" is also considered to be a popular policy driver of restrictive immigration policies in Europe (p.20). According to Bader (2005), welfare chauvinism is one of the arguments used in anti-immigration rhetoric to defend the need for migration restrictions. Securitisation process of the migration also brings together different agents such as securitising actors and audiences or the elites and the public, under the shared understanding of a perceived threat that requires to use all means to restrain its development (Karyotis, 2012, p. 391). Thus as "enemies at the gate" (Esses, Medianu \& Lawson, 2013) who pose an impending threat to the receiving nations; media frames play a crucial role in constructing the migrants (Esses, Medianu $\&$ Lawson, 2013). Overall, through a number of subframes, the thereat frame invokes a 'moral panic' (Gabrielatos \& Baker, 2008) of a perceived 'threat to a sovereign state' (Innes, 2010) from the 'enemies at the gate' (Esses, Medianu \& Lawson, 2013). 
The personalised or emotionalised perspective of the human-interest frame (Steimel, 2010) is highlighted through the victimisation frame. The perilous situations migrants have to face, such as being battered by tear gas or drowned in the sea while escaping war and conflict were mainly highlighted through this frame. For instance, most reports refer to rescue missions from life-threatening situations. While some finds safety most faces an unfortunate demise.

"Up to 117 migrants might have died when a rubber dinghy capsized in the Mediterranean off Libya, survivors said. International Organisation for Migration, said three survivors were plucked to safety by an Italian navy helicopter on Friday, and they said 120 were aboard when the dinghy left Libya."

(Express and Star, 2019c)

Similarly, it also portrays bureaucratic hurdles that burden immigrants such as "the case of a family at risk of deportation because they cannot afford the Home Office fee to process their application" (McArdle, 2019). In some instances, the victimisation frame was also used as an instrument for political criticism too. For instance, the Scottish first ministers claim that migrants' suffering is an "illustration of Tory-run Britain" which "is absolutely shocking and appalling,". Conversely stating that Labour party and she, in particular, are "hugely sympathetic to those who have real difficulties navigating the complex and the increasingly restrictive UK immigration rules" (McArdle, 2019)

Xenophobia, hostility, bullying and other forms of racist violence also contribute to a considerable portion of the frame.

"This woman just started shouting at me saying that I was in an English-speaking country, so why didn't I just learn the language. I felt really angry. "Why would people say stuff like that when they don't know me? I am talking in my mother tongue, which I didn't want to lose because it is part of who I am.” (Denholm, 2019)

The victimisation frame also focusses on the perspectives of the immigrants speculating on the reasons why they leave, especially of those who are fleeing from fleeing oppressive conditions, conflict or dire economic conditions.

"I had nothing to lose. We are treated as an object, like a slave. I wanted to tell people my story and about what happens to Saudi women. I'm sure that there will be a lot more women running away. I hope my story encourages other women to be brave and free." (Randhawa, 2019)

All the above subframes, such as tragic victims, legal restrictions, facing racism hostility and xenophobia suggest that they are in dire need of support as they have faced circumstances that are beyond their own responsibilities and actions (Horsti, 2008). As a result of these detailed insights into their situation, the victimisation frame calls the moral obligations of the reader. However, according to some researchers the above frame, "it is particularly well suited in news coverage of immigration as it avoids the more complex dimensions related to laws, statistics, and political arguments" and emphasise an emotional angle to present an issue (Aalberg \& Beyer, 2015 p. 859).

Unlike the previous frames that mainly evoked negative connotations the next two frames Economization and migrant voices evoked more mixed attitudes. While articles with anti-Brexit stance suggested the need for immigrants and positive reinforcement towards immigrants as a boost to the economy the other news stories aligned with above threat and fear frames.

Migrant voice frame brings the migrant perspectives, that discusses their triumphs, success stories as well as issues of integration. Although they tend to celebrate the accomplishments achieved through hard work, it also focuses on various difficulties immigrant have 
faced during their journeys. Further, some of them even discuss their contributions to society to make the lives of other immigrants a better one. Although it was not used by all regional newspapers, Express and Star and Manchester Evening News, both newspapers that mostly adopted the threat frame also did publish articles that celebrated migrant triumphs.

Studies have viewed economisation frame in different viewpoints; while some view it as an economic burden and a threat (Greussing \& Boomgaarden, 2017), others view it in a positive light as a benefit (Crawley, McMahon \& Jones, 2016). Like the latter, this study also examines the economic benefits of immigration as well as the issues the country's economy has to face when migration is restricted. While adverse effects of immigration control are clearly portrayed with reference to the private sector, concerns of the government institutions seem to have a stronger appeal. This is particularly evident in issues related to the service sector. Several mentions were made in reference to National Health Services, which is even being highlighted by elite figures such as Bishop of London, Dame Sarah Mullally.

\begin{abstract}
"Even before the referendum, almost $15 \%$ of all nursing posts in the capital were vacant according to the Royal College of Nursing. On top of those existing recruitment pressures, the clear effect of just the prospect of Brexit has been to drive more and more EEA nurses out of the NHS, and tighter immigration controls would only exacerbate the problem. We risk making the NHS less safe." (Cecil, 2019)
\end{abstract}

\title{
5.1. Shift in Frames
}

During the first time point, which marked the publication of the Brexit withdrawal agreement, the regional press discourse mainly adopted the humanitarian narrative. However, a shift from the humanitarian frame was visible during the second time point in the latter part of January. While the data from the third time-point indicated that the discourse again adopted the humanitarian frame, the above shift during late January is a unique phenomenon. It was particularly noticed in The Express and Star and Manchester Evening News. Further, the same period also saw a reduction of the humanitarian frame in both Herald and Evening Standard and an increase in the number of articles under their threat fame. The surge in the humanitarian frame was particularly related to the news stories on the continuing issue of immigrants crossing the English Channel from Calais-France, organised groups that carried those activities, elite actors such as home secretary and immigration minister expressing their concerns about national security and calling for action as well as joint security activity with French Border security to eliminate the threat. The call for action as well as the heightened threat of the situation can be considered as a clear example for Innes (2010) explanation of "threatened becoming the threat" where "individual human insecurity is seen as threatening a sovereign state" (p. 456).

Morrison (2019) also reports a similar shift in frames claiming that the shift in discourse was a clear example of how the press could reframe the discourse reversing the media agenda-setting. The dominant anti-immigrant discourse that highlighted the immigrants exploiting public services and social security was changed towards implications of losing skilled foreign workers that emphasised the 'economic nationalist' frames during the immediate post-referendum period (Morrison, 2019). The abrupt shift took place while other key actors were trying to make sense of the referendum result reflecting in the media's ability to reverse and reframe a debate (Morrison, 2019). Although the above shift was not a reframe but a 'moral panic' (Gabrielatos $\&$ Baker, 2008) that was heightened by the threat rhetoric of the state actors. 


\subsection{Regional Analysis}

It is also worth noting that among the examined newspapers, the most circulated ones like The Evening Standard, The Express and Star, The Herald carried most number of articles related to immigrants. However, that did not correspond with the number of migrants living in the area. Although $36 \%$ of all the migrants in the UK live in London, which also contributes to $38 \%$ of its total population, The Evening Standard did not produce the most number of articles related to immigrants. Whereas West midlands and Scotland with migrant populations at $8 \%$ and $5 \%$ (Rienzo \& Vargas-Silva, 2018) contributed to the migration-related news mostly. Among the ten newspapers, Express and Star and Manchester Evening news predominantly used the threat frame in their coverage. Apart from the above regions, other regions produced a little number of news stories that are related to immigrants and mostly with a humanitarian standpoint.

Among all the regions, with immigrants being 9\% of the entire Scottish population (Rienzo \& Vargas-Silva, 2018), Scotland's case is particularly noteworthy as both Scottish newspapers, The Herald and Scotsman, contributed to the immigration news stories, mostly framing it in a positive manner through humanitarian, migrant voices and economisation frames. It was further noted that most of the article, regardless of the frame, valued migrant contribution and both culturally and economically and had a positive note in the articles. These finding could be well linked to the Scottish political leaning and the general decrease in population and labour force.

As a region who voted to remain in European Union at the 2016 referendum which had the highest vote share for remain at $62 \%$ with Edinburgh voting over $74 \%$ (BBC, 2016b) Scotland is clear in its open arms policy towards immigrants.

"All the workers we need will be welcome here, and they and their families will be treated fairly,"

It is foolish and reckless to change our immigration system in this way without first knowing what our future relationship with the EU will be." (Nis, 2019)

In addition, in pursuit of making Scotland a safe space for immigrant children an anti-bullying campaign was initiated at the school level to prevent "racist bullying of Eastern European pupils in Scotland" which has "escalated since Brexit, with victims hiding their nationality to avoid being targeted".

Mostly, articles related to the economic frame highlighted the potential damages to the Scottish economy. These claims were directly linked to the new migration regulation related to European labour, such as the minimum salary threshold of $£ 30,000$. This seems to be a particular concern for the Scottish government as the minimum salary in the region is estimated to be around $£ 18,000$, which would result in a decrease in the flow of workers from EU nations. As of September 2018, 145,000 EU nationals were working in Scotland. These fears are also predicting a decline in the number of overseas citizens working in Scotland which currently is around 26,000 in health and social care and 29,000 in accommodation and food services (Grant, 2019).

"The proposed salary threshold would apply to 1.5 million jobs in Scotland and would hammer key sectors of our economy and vital public services like our NHS. (Grant, 2019)

Overall, with a declining and an ageing population with a tendency for young adults to migrate towards the central cities such as Glasgow and Edinburgh (Catto, Gorman, \& Higgins, 2010), Scotland's need for migrants is evident. Similar to the prominence of the human- 
itarian frame, other studies based exclusively on Scottish press frames place immigrant in a positively highlighting their need and importance through concerns for the economy, population decline, filling of gaps in the NHS and Scotland as a less vulnerable region than rest of the UK (Catto, Gorman \& Higgins, 2010, p. 767).

Britain's migrant population is concentrated in London, with approximately $35 \%$ of the foreign-born population living in the capital, compared with $14 \%$ for the UK as a whole (Sturge, 2019). Further, the South West region of the UK enjoys the most employment rates at $79.9 \%$ (ONS, 2019). As the city with the most number of immigrants living, London was clear in its humanitarian frame. However, in the West Midlands, the threat frame was dominant than the humanitarian frame. It also rings at the results of the referendum's leave vote, where West Midlands had the highest vote share for Leave at 59.3\% (BBC, 2016b). However, after London, West Midlands is one of the English Regions with the highest foreign-born populations (Sturge, 2019).

Further, unlike in Scotland, in other areas, the connection between referendum vote and the dominant frame is not clear. One factor is the examined newspaper in each region covers the entire region, which consists of several electorates. For instance, in the North East other than Newcastle, all other areas voted to leave (The Electoral Commission, 2016). Nevertheless, the humanitarian frame is more prominent in the Evening Chronicle's immigration news. The same could be said of Manchester where threat frame was dominant. This also could depend on a number of reasons among which newspapers political leaning and the shortness of the examined time period being the main causes. According to Eshbaugh-Soha (2010), newspapers try to provide news that could attract audience attention and engagement. However, scholars note that the readers get an understanding of the local community through representations in communications by the local media that also control the moral boundaries of community (Shah, McLeod \& Yoon, 2001). This ideological power of the media then creates political and social issues in the communities (Smith, 1984).

\section{Conclusion}

Immigration is not a mere British problem. However, over the years, it has become one of the most salient issues for the British public. Given its salience and the political uncertainty that surrounded Brexit, this study was set out to examine the portrayal of immigrants in the British regional press. The finding relates to both positive and negative frames that indicates the complexity of immigration and differing perspectives surrounding it.

One of the most notable aspects regarding the study's finding is the predominance of the humanitarian frame. It challenges the stereotype of the established national discourse while highlighting the British public's supportive and welcoming culture, dismissing myths about immigrants, securing justice for them and even facing the consequences for aiding migrant groups. Nevertheless, the threat frame was not far behind. It also portrays a combination of issues such as migrants crossing the English Channel, immigration control laws and policies of Brexit that aim to regulate movement, joint security measures with the French government and issues that have arisen with the increasing migrant numbers that are closely linked to national security concerns. The threat frame also relates to the stereotypical depictions of migrants as criminals, involved in illegal activities that pose a danger and a threat to public order and safety of the British people and for using illegal means that evokes suspicion and preju- 
dice. Two newspapers, in particular, The Express and Star and the Manchester Evening News, provided a negative representation, which showcased most stories via the threat frame. Meanwhile, in another negative angle, the victim frame depicts the migrants as people facing disadvantaged situations while highlighting them in a desperate plight often positions them as passive victims in circumstances which they are not responsible.

As a multicultural country, migrant contributions cannot be forgotten. The migrant voices frame mainly celebrates migrants and their success stories as key players in the society who are crucial to the globalised country. Migrant voice also provides a space for migrants to reflect on their journeys in a retrospective manner that depicts their hardships and difficulties in integration while battling racism and xenophobia. Meanwhile, the economisation frame discusses the contribution of migrant labour in the development of the economy, its economic benefits as well as the importance of maintaining migrant labour in the future under new Brexit policies.

Conversely, the Scottish media discourse highlighted its pro-immigrant stance and the open arm policy towards the immigrants, through the two Scottish newspapers The Herald (Glasgow) and Scotsman (Edinburgh). Although the other regional newspapers (Yorkshire Post, South Wales Echo, Yorkshire Evening Post etc.) took a stance towards humanitarian frame, the number of article that were produced by them during the three time-points were quite limited compared to the immigrants' news by Evening Standard (London), Herald (Glasgow) and Express and Star (West Midlands). However, the shift in the frames from a humanitarian narrative to the threat, shows a reframing of the discourse. Such a reframing is clear indication how the press could be swayed by the threat rhetoric of the state actors.

In terms of the limitations of the study, it should be noted that the length of the time period is not sufficient to acquire an extensive data set where a higher number of immigration-related articles could be collected. Further content from larger number of newspapers could have provided more data as well as a better representation of the public perception of immigrants.

Findings also highlight the valence of news frames and the necessity of understanding news frames as they influence an individual's analysis of current affairs (de Vreese, 2005) which holds the power to sway the public perception on a convoluted policy matter as immigration. As mentioned in the literature, regional press's portrayal during the time leading up to the 2015 election claim that newspapers tend to reinforce negative stereotypes while providing very little space for migrants to voice out their opinions (Crawley, McMahon \& Jones, 2016). Overall, KhosraviNik, Wodak and Krzy ¿anowski (2012) note that the "conservative broadsheet creates a more sophisticated xenophobic representation of refugees, asylum seekers and immigrants, while the tabloid is at ease in reproducing the existing prejudices and positions as a consumer of negativity" ( $p$ 294). While the national media representations are mostly negative with victim and threat frames (Berry, Garcia-Blanco \& Moore, 2015; Huysmans \& Buonfino, 2008) some studies have suggested that regional media depicts immigrant news in a positive manner (Catto, Gorman \& Higgins, 2010), others argue it follows the stance of the national press (Rasinger, 2010; Walter, 2019). Similar to the results of this study, findings of Catto, Gorman and Higgins (2010) and Finney and Robinson's (2008) suggest that through local discourse issues are framed and constructed differently by the local press in different locations.

As noted in the other studies too, this study also confirms that the act of framing creates a link between those topics or issues which results in certain judgements about its consequences and impact on society (Crawley, McMahon \& Jones, 2016). However, there is a great 
possibility in "reversing such stereotypical labelling" via the creation of awareness about immigrants' "positive contributions to their host societies". But it requires the "press to provide a more accurate, unbiased and realistic portrayal of migrants" (European Commission, 2011, p. 9). But it also confirms framing's ability to challenge stereotypes or heighten insecurities of the audiences. However, according to scholarly evidence, immigration in the UK and around the world is mostly framed negatively, although few regional studies have shown the possibility of finding a positive outcome.

The finding also reaffirm the factors that influence news frames, specially the importance of those that renders an understanding about media portrayals such as regional, political and social contexts where news is produced (de Vreese, Peter \& Semetko, 2001). Therefore, what emerges prominently is the importance of understating the requirements of the local community. Although the Scottish portrayal is the most hopeful one, the depiction of immigrants in the regional press is a complex amalgamation of many opinions. This also could be a reason why immigration is a highly contested topic. Thus, confirm the necessity of giving space to the local voices as they provide better insights into the matter.

\section{References}

Aalberg, T., \& Beyer, A. (2015). Human interest framing of irregular immigration: An empirical study of public preferences for personalized news stories in the United States, France, and Norway. American Behavioral Scientist, 59(7), 858-875.

ABC (2018). Regional Daily ABCs, 28 February. Available at: https://www.pressgazette. co.uk/ regional-daily-abcs-ipswich-star-falls-hardest-as-print-circulations-tumble-across-dailies/(Accessed: 11 February 2019).

Bader, V. (2005). The ethics of immigration. Constellations, 12(3), 331-361.

Balabanova, E., \& Balch, A. (2010). Sending and receiving: The ethical framing of intra-EU migration in the European press. European Journal of Communication 25(4): 382-397.

Balch, A., \& Balabanova, E. (2016). Ethics, Politics and Migration: Public Debates on the Free Movement of Romanians and Bulgarians in the UK, 2006-2013. Politics, 36(1), 19-35. https://doi.org/10.1111/14679256.12082

BBC (2016a). [Twitter] 22 June. Available at: https://twitter.com/BBCNews (Accessed: 18 June 2019).

BBC (2016b). EU referendum: The result in maps and charts, Available at : https://www.bbc.co.uk/news/ukpolitics-36616028 (Accessed on 4th June 2019)

BBC News (2002). Blunkett stands by swamping remark. BBC Online. 25th April. Available at: http://news.bbc.co.uk/1/low/uk_politics/1949863.stm (Accessed on 4 May 2019)

BBC News (2015). David Cameron criticised over migrant 'swarm' language, BBC News. 30 July Available at: http://www.bbc.co.uk/news/uk-politics33716501 (Accessed on 4 May 2019)

Benson, R. (2014). Shaping immigration news: A French-American comparison. Cambridge: Cambridge University Press.

Berry, M., Garcia-Blanco, I., \& Moore, K. (2015). Press coverage of the refugee and migrant crisis in the EU: A content analysis of five European countries. Report prepared for the United Nations High Commission for Refugees. Available at: https://www.unhcr.org/protection/operations/56bb369c9/press -coverage-refugee-migrant-crisis-eu-content-analysis-five-european.html (accessed 4 January 2019).

Beutin, R., Canoy, M., Horvath, A., Hubert, A., Lerais, F., \& Smith, P. (2006). Migration and public perception Brussels: European Commission: Bureau of European Policy Advisers (BEPA), European Commission.

Blinder, S., \& Allen, W. (2016). Constructing Immigrants: Portrayals of Migrant Groups in British National Newspapers, 2010-2012. International Migration Review 50 (1): 3-40.

Blinder, S., \& Jeannet, A.M. (2018). The 'illegal 'and the skilled: effects of media portrayals on perceptions of immigrants in Britain. Journal of Ethnic and Migration Studies, 44(9), 1444-1462. 
Bourbeau, P. (2011). The Securitization of Migration: A Study of Movement and Order. London: Routledge. Breen, M. J., Haynes, A., \& Devereux, E. (2006). Fear, Framing and Foreigners: The Othering of Immigrants in the Irish Print Media. International Journal of Critical Psychology, 16, 100-121.

Bridger, B. (2019). Knightsbridge restaurant could lose license over 'illegal staff and threats' after being raided by Border Force. January 15, The Evening Standard. Available at: https://www.standard.co.uk/news/london/knightsbridge-restaurant-could-lose-licence-over-illegal-staff-and-threats-after-being-raided-by-a4039 081.html (Accessed on 5th June 2019)

Buchanan, S., Grillo, B., \& Threadgold, T. (2004). What's the Story? Results from Research into Media Coverage of Refugees and Asylum Seekers in the UK. Forced Migration Review, (19), 41-43.

Busby, E. (2018). Delivered to no 10: 12,000 pleas to help children escape the trauma of war. The Evening Standard (London) November 20. Available at: https://www.standard.co.uk/news/learntolive/pupils-deliver-petition-to-downing-street-with-12000-pleas-to-help-children-escape-war-traumas-a3994581.html (Accessed on 24th June 2019)

Carl, N. (2018). CSI Brexit 4: Reasons Why People Voted Leave or Remain. Centre for Social Investigation, Available at: http://csi.nuff.ox.ac.uk/wpcontent/uploads /2018/04/Carl Reasons _Voting.pdf. (Accessed on 24th March 2019)

Carvalho, J., Eatwell, R., \& Wunderlich, D. (2015). The Politicisation of Immigration in Britain. In W. van der Brug, G. D'Amato, J. Berkhout, \& D. Ruedin (Eds.). The politicisation of migration (pp. 159-178). London: Routledge.

Catto, A., Gorman, D., \& Higgins, M. (2010). The impact of recent Central and Eastern European migration on the Scottish health service: A study of newspaper coverage 2004-2008. Health \& place, 16(5), 765-775.

Caviedes, A. (2015). An emerging 'European' news portrayal of immigration? Journal of Ethnic and Migration Studies, 41(6), 897-917. https://doi.org/10.1080/1369183X. 2014.1002199

Cecil, N. (2019). Bishop of London says Brexit impact on nurses' risks making NHS less safe, The Evening Standard (London), January 16, 2019.

Charteris-Black, J. (2006). Britain as a container: Immigration metaphors in the 2005 election campaign. Discourse \& Society,17(5), 563-581. https://doi.org/10.1177/09579 26506066345

Cheregi, B.F. (2015). The discursive construction of Romanian immigration in the British media. Romanian Journal of Communication and Public Relations, 17(2), 53-73.

Chong, D., \& Druckman, J.N. (2007). Framing theory. Annu. Rev. Polit. Sci., 10, 103-126.

Chouliaraki, L., \& Zaborowski, R. (2017). Voice and community in the 2015 refugee crisis: A content analysis of news coverage in eight European countries. The International Communication Gazette, 79(6-7): 613-635.

Clarke, H., Goodwin, M., \& Whiteley, P. (2017). Brexit-Why Britain Voted to Leave the European Union. University of Essex Publication.

Cohen, S. (1980). Folk Devils and Moral Panics: The Creation of the Mods and Rockers (New Edition). Oxford, UK: Martin Robertson.

Connolly, S. (2019). Johnson says immigration controls will boost pay, The Herald, January 18.

Corbett, S. (2016). The Social Consequences of Brexit for the UK and Europe: Euroscepticism, Populism, Nationalism, and Societal Division. International Journal of Social Quality, 6 (1). 11-31.

Crawley, H., McMahon, S., \& Jones, K. (2016). Victims and Villains: Migrant Voices in the British Media. Centre for Trust, Peace and Social Relations, Coventry University, Coventry.

de Beer, S., \& Merrill, C. (2004). Global Journalism: Topical Issues and Media Systems. 4th ed. Boston: A1lyn \& Bacon.

de Vreese, C. H. (2005). News framing: Theory and typology. Identifying information and tenor in texts. Information Design Journal, 13(1), 51-62.

de Vreese, C. H., \& Lecheler, S. (2012). News framing research: An overview and new developments. The SAGE Handbook of Political Communication, 292-306.

de Vreese, C.H, \& Boomgaarden, H. (2003). Valenced news frames and public support for the EU. Communications, 28(4), 361-381.

de Vreese, C.H., Peter J., \& Semetko, H. A. (2001). Framing politics at the launch of the Euro: A cross-national comparative study of frames in the news. Political communication, 18(2), 107-122. 
Denholm. A. (2019). I was scared to talk because I thought I would be mocked, The Herald April 6, Available at: https://www.heraldscotland.com/news/17554555.i-was-scared-to-talk-because-i-thought-i-wouldbe-mocked/ (Accessed on 10th June 2019)

Dennison, J., \& Geddes, A. (2018). Brexit and the perils of 'Europeanised' migration. Journal of European Public Policy, 25:8, 1137-1153, DOI: 10.1080/13501763.2018.1467953

D'Haenens, L., \& De Lange, M. (2001). Framing of asylum seekers in Dutch regional newspapers. Media, Culture \& Society. Nov; 23(6):847-60.

Druckman, J. N. (2001). The implications of framing effects for citizen competence. Political Behavior, 23, 225-256. doi:10.1023/A:1015006907312

Duffy, B., \& Frere-Smith T. (2014). Perceptions and Reality: Public Attitudes to Immigration. London: IpSOS MORI.

Entman, R. M. (1993). Framing: Toward clarification of a fractured paradigm. Journal of Communication, 43, 4-52.

Eshbaugh-Soha, M. (2010). The tone of local presidential news coverage. Political Communication, 27(2), 121-140.

Esses V. M, Medianu S., \& Lawson A.S. (2013). Uncertainty, threat, and the role of the media in promoting the dehumanization of immigrants and refugees. Journal of Social Issues 69(3): 518-536.

Eurobarometer (2016). TNS opinion, Brussels [producer]. GESIS Data Archive, Cologne. ZA6788 Data file Data file Version 1.4.0, doi:10.4232/1.13313

European Commission. (2011). Eurobarometer Qualitative Study - Migrant Integration: European Commission Available at: https://ec.europa.eu/commfrontoffice/publicopinion/archives/quali/ql_5969_migrant _en.pdf. (Accessed on 5 June 2019)

Express and Star (2018a). May's plans for post-Brexit immigration system attacked by employers 19 November. https://www.expressandstar.com/news/uk-news/2018/11/19/mays-plans-for-post-brexit-immigrationsystem-attacked-by-employers/

Express and Star (2018b). Syrian refugee, 15, fears school after playing field attack', 28 November. https://www.expressandstar.com/news/uk-news/2018/11/28/syrian-refugee-15-fears-school-after-attack/

Express and Star (2018c). Italy's anti-migrant interior minister welcomes refugees 'escaping war. November 14. Available at: https://www.expressandstar.com/news/world-news/2018/11/14/italys-anti-migrantinterior-minister-welcomes-refugees-escaping-war/ (Accessed on 4th May 2019)

Express and Star (2019a). Sajid Javid defends questioning how 'genuine' English Channel refugees are, January 7. Available at: https://www.expressandstar.com/news/uk-news/2019/01/07/sajid-javid-defendsquestioning-how-genuine-english-channel-refugees-are/(Accessed on 4th May 2019)

Express and Star (2019b). French step up measures to counter cross-Channel migrant boats. January 4. Available at: https://www.expressandstar.com/.../french-step-up-measures-to-counter-cross- channel-migrant-boats/ (Accessed on 5th May 2019)

Express and Star (2019c). Dozens of migrants feared dead after boat capsizes off Libya. January 19, Available at: https://www.expressandstar.com/.../world.../dozens-of-migrants-feared-dead- after-boat-capsizes-off-libya/ (Accessed on 10th May 2019)

Finney, N., \& Robinson, V. (2008). Local press, dispersal and community in the construction of asylum debates. Social \& Cultural Geography, 9(4), 397-413.

Ford, R. \& Goodwin, M. (2014) Understanding UKIP, identity, social change and the left behind, Political Quarterly. 85(3),277-284

Fox, B. (2018). Making the Headlines: EU Immigration to the UK and the Wave of New Racism After Brexit. In: Balica E., Marinescu V. (eds) Migration and Crime (pp. 87-107). Palgrave Macmillan, Cham. https://doi.org/10.1007/978-3-319-95813-2_5

Fox, J.E., Moroşanu, L., \& Szilassy, E. (2012). The racialisation of the new European migration to the UK. Sociology 46(4): 680-695.

Gabrielatos, C., \& Baker, P. (2008). Fleeing, sneaking, flooding: A corpus analysis of discursive constructions of refugees and asylum seekers in the UK press, 1996-2005. Journal of English linguistics, 36(1), 5-38.

Gerbner, G. (1969). Toward "cultural indicators": The analysis of mass mediated public message systems. Educational Technology Research and Development, 17(2), 137-148. 
Goffman, E. (1974). Frame analysis: An essay on the organization of experience. Boston, MA: Northeastern University Press

Grant, A. (2019). Immigration plans 'cruel' as 1.5m jobs pay under £30k, The Herald (Glasgow). April 9, p. 4.

Gray, H., \& Franck, A.K. (2019). Refugees as/at risk: The gendered and racialized underpinnings of securitization in British media narratives. Security Dialogue, 50(3), 275-291.

Greussing, E., \& Boomgaarden, H.G. (2017). Shifting the refugee narrative? An automated frame analysis of Europe's 2015 refugee crisis. Journal of Ethnic and Migration Studies, 43(11), 1749-1774.

Hartmann, P., Husband, C., \& Clark, J. (1974). Race as news: A study in the handling of race in the British national press from 1963-1970. Race as news, 9-171. Paris: UNESCO.

Hartmann, P.G., \& Husband, C. (1974) Racism and the mass media: A study of the role of the mass media in the formation of white beliefs and attitudes in Britain. London: Davis-Poynter.

Holden, J. (2019). Javid under pressure as immigration bill passes first Commons stage, The Herald, January 29, p.4.

Holland. D. (2019). New hope in council's fight to stop asylum seekers being forced to share rooms with strangers; A new firm will be providing accommodation for asylum seekers under a new contract, chroniclelive.co.uk. March 30. Available at: https://www.chroniclelive.co.uk/news/north-east-news/new-hopecouncils-fight-stop-16048687 (Accessed on 4th June 2019)

Horsti, K. (2008). Europeanisation of public debate: Swedish and Finnish news on African migration to Spain. Javnost-the public, 15(4), 41-53.

Huysmans, J. (2000). The European Union and the securitisation of migration. JCMS: Journal of Common Market Studies 38(5): 751-777.

Huysmans, J. (2006). The politics of insecurity: Fear, migration and asylum in the EU. London, UK: Routledge. Huysmans, J. (2008). The jargon of exception — on Schmitt, Agamben and the absence of political society. International political sociology, 2(2), 165-183.

Huysmans, J., \& Buonfino, A. (2008). Politics of exception and unease: Immigration, asylum and terrorism in parliamentary debates in the UK. Political studies, 56(4), 766-788.

Innes, A. (2010). When the threatened become the threat: The construction of asylum seekers in British media narratives. International Relations 24(4): 456-477.

Ipsos M.O.R.I (2014). Economist/Ipsos MORI Issues Index - November 2014, Available at https://www.ipsos-mori.com/researchpublications/researcharchive/3484/Economist Ipsos-MORI-Issues-Index-November-2014.aspx (Accessed 12 February 2019).

Ipsos, M.O.R.I., (2016) 4 ways anti-immigration vote won referendum brexit. [Online article] available from https://www.ipsos.com/ipsos-mori/en-uk/4-ways-anti-immigration-vote-won-referendum-brexit [Accessed 15 May 2019].

Iyengar, S. (1991). Is anyone responsible? How television frames political issues. Chicago, IL: University of Chicago Press

Joppke, C. (1999). Immigration and the Nation-State: The United States, Germany and Great Britain. Oxford: Oxford University Press.

Kahneman, D., \& A. Tversky. 1979. Prospect Theory: Analysis of decision under risk. Econometrica 47(2): 263-291.

Karyotis, G. (2012). 'Securitization of migration in Greece: Process, motives, and implications'. International Political Sociology 6(4): 390-408.

KhosraviNik, M., Wodak, R., \& Krzyzanowsky, M. (2012). Dynamics of Representation in Discourse: Immigrants in the British Press. In: M. Messer, R. Schroeder and R. Wodak (eds.) Migrations: Interdisciplinary Perspectives (pp.283-295). Berlin: Springer-Verlag.

Lawlor, A. (2015). Framing immigration in the Canadian and British news media. Canadian Journal of Political Science/Revue canadienne de science politique, 48(2), 329-355.

Lawlor, A., \& Tolley, E. (2017). Deciding who's legitimate: News media framing of immigrants and refugees. International Journal of Communication. vol. 11, 967-991.

Lecheler, S., \& De Vreese, C.H. (2012). News framing and public opinion: A mediation analysis of framing effects on political attitudes. Journalism \& Mass Communication Quarterly, 89(2), 185-204. 
Lemish, D. (2000). The whore and the other: Israeli images of female immigrants from the former USSR. Gender and Society 14, 333-349. doi:10.1177/089124300014002007

Leonard, S. (2010). EU border security and migration into the European Union: FRONTEX and securitisation through practices. European Security, 19 (2), 231-254.

Light, D., \& Young, C. (2009). European Union enlargement, post-accession migration and imaginative geographies of the 'New Europe': media discourses in Romania and the United Kingdom. Journal of Cultural Geography, 26:3, 281-303, DOI: 10.1080/08873630903322205

Liverpool Echo (2019). Nokes pledges to return migrants, January 26.

Manchester Evening News (2018). Pupils screened for TB. November 28. Available at : https://www.manchestereveningnews.co.uk/news/greater-manchester-news/tb-st-cuthberts-primary-withington-15468874 (Accessed on 6th June 2019)

McArdle, H. (2019). Family facing deportation can't afford fee for bid to stay. The Herald (Glasgow) March 29.

McCollum, D., \& Findlay, A. (2011). Employer and labour provider perspectives on Eastern European migration to the UK. CPC Working Paper Number 14. Southampton: ESRC Centre for Population Change.

McLaren, L., \& Johnson, M. (2007). Resources, group conflict and symbols: Explaining anti-immigration hostility in Britain. Political Studies, 55(4), 709-732.

Mohamed, H., \& Farris, E. (2019). 'Bad hombres'? An examination of identities in U.S. media coverage of immigration. Journal of Ethnic and Migration Studies, 46(1), 158-176. doi: $10.1080 / 1369183$ X.2019.1574221

Moore, S. (2016). The message of Brexit was mixed. Now we are told it was simply a referendum on immigration, The Guardian, 5th October. Available at https://www.theguardian.com/commentisfree/2016/oct/05/ the-message-of-brexit-was-mixed-now-we-are-told-it-was-simply-a-referendum-on-immigration (Accessed 15th July 2019)

Morrison, J. (2019). Re-framing free movement in the countdown to Brexit? Shifting UK press portrayals of EU migrants in the wake of the referendum. The British Journal of Politics and International Relations, 21(3), 594-611.

Moses, J. (2006). International Migration: Globalization's Last Frontier. London: Zed Books

Murphy, J. (2018). Cabinet at war over plan to block key workers The Evening Standard, November 27.

Newman, N., Fletcher, R., David, A., Levy, D.A., \& Nielsen, R.K. (2016). Digital news report 2016. Reuters Institute for the study of Journalism.

Nis, P. G. (2019). Labour's Diane Abbott hints at free movement policy shift, Scotsman April 11, Available at https://www.scotsman.com/news/politics/general-election/labour-s-diane-abbott-hints-at-free-movement-policy-shift-1-4906123 (Accessed on 27th June 2019)

Nisbet, M. C., Brossard, D., \& Kroepsch, A. (2003). Framing science: The stem cell controversy in an age of press/politics. Harvard International Journal of Press/Politics, 8(2), 36-70.

Nokes, C. (2019). Brexit: We want EU citizens to stay - Immigration Minister Caroline Nokes, Scotsman March 29. https://www.scotsman.com/news/opinion/brexit-we-want-eu-citizens-to-stay-immigration-ministercaroline-nokes-1-4897807

Office for National Statistics (2016). Population dynamics of UK city regions since mid-2011, Available at https://www.ons.gov.uk/peoplepopulationandcommunity/ population andmigration/populationestimates/articles/populationdynamicsofukcityregionssincemid2011/2016-10-11 (Accessed: 12 February 2019).

Office for National Statistics (2019). Regional labour market statistics in the UK: March 2019, Available at: https://www.ons.gov.uk/employmentandlabourmarket/peopleinwork/ employmentandemployeetypes/bulletins/regionallabourmarket/march2019 (Accessed: 12 July 2019).

Ormston, R. (2015). Do we feel European and does it matter? NatCen British Social Attitudes. Available at: https://ukandeu.ac.uk/explainers/do-we-feel-european-and-does-it-matter/ (accessed on 24th May 2019)

Page, B. (2009). British Attitudes to Immigration in the 21st Century. Washington, DC: Migration Policy Institute.

Paterson, L. (2019). Some Scots communities might no longer exist' under migration cuts, Scotsman, April 4. https://www.scotsman.com/news-2-15012/some-scots-communities-might-no-longer-exist-under-migration-cuts-1-4901638(accessed on 24th May 2019) 
Paul, K. (1997). Whitewashing Britain: Race and Citizenship in the Post war Era. Ithaca, NY: Cornell University Press.

Philo, G., Briant, E., \& Donald, P. (2018). Bad News for Refugees. London: Pluto Press.

Poole, E., \& Richardson, J.E. (eds) (2010). Muslims and the News Media. New York: IB Tauris.

Randhawa, K. (2019). Rahaf Mohammed: I feel born again, says Saudi who fled to Canada to escape 'abuse' Evening Standard. January 15. Available at: https://www.standard.co.uk/news/world/i-feel-born-againsays-saudi-who-fled-to-canada-to-escape-abuse-a4039351.html (Accessed on 11th June 2019)

Rasinger, S. M. (2010). Lithuanian migrants send crime rocketing': representation of 'new' migrants in regional print media. Media Culture \& Society 32(6): 1021-1030.

Rienzo, C., \& Vargas-Silva, C. (2018). 'Migrants in the UK: An Overview'. Migration Observatory briefing, COMPAS, University of Oxford. Available at: https://migrationobservatory.ox.ac.uk/resources/briefings/migrants-in-the-uk-an-overview/ (Accessed on 2 August 2019)

Scammell, M., \& Semetko. H. A. (2008). Election News Coverage in the U.K. In J. Stromback and L. L. Kaid (eds.) The Handbook of Election News Coverage Around the World (pp. 73-89). London and New York: Routledge.

Scheufele, D. A., \& Iyengar, S. (2014). The state of framing research: A call for new directions. In K. Kenski \& K. H. Jamieson (Eds.). The Oxford handbook of political communication theories (pp. 1-26). New York, NY: Oxford University Press.

Scott, J. (2019). Drugs courier caught with $£ 200,000$ of cocaine and $£ 56,000$ cash in Bilston car park. Express and Star. January 8. Available at: https://www.expressandstar.com/news/crime/2019/01/18/albanian-aged-18-arrested-with-cocaine-worth-200000-and-56000-cash-locked-up-for-over-4-years/ (Accessed on 5th June 2019)

Shah, D.V., McLeod, J.M., \& Yoon, S. (2001). Communication, context and community. An exploration of print, broadcast and internet influences. Communication Research 28: 464-506.

Smith, D., \& Deacon, D. (2018). Immigration and the British news media: Continuity or change? Sociology Compass, 12(9), p.e12618.

Smith, S. J. (1984). Crime and the structure of social relations. Transactions of the Institute of British Geographers 9: 427-442.

Smith, D. (2019). How a penniless asylum seeker built a life in the UK; Dino Doyd came to this country with nothing, before building a business and finding a family, chroniclelive.co.uk. April 8. https://www.chroniclelive.co.uk/news/uk-news/how-penniless-asylum-seeker-built-16095844

Sniderman, P.M., \& Theriault, S.M. (2004). The structure of political argument and the logic of issue framing. Studies in public opinion: Attitudes, nonattitudes, measurement error, and change, 133-165.

Sobolewska, M., Galandini, S., \& Lessard-Phillips, L. (2016). The public view of immigrant integration: multidimensional and consensual. Evidence from survey experiments in the UK and the Netherlands. Journal of Ethnic and Migration Studies 43(1): 58-79.

Sogelola, D. (2018). Brexit, Agenda Setting and Framing of Immigration in the Media: The Case of the Daily Mail. LSE Undergraduate Political Review. Vol 1, 128-142 DOI: http://dx.doi.org/10.21953/ 1se.btysqags6o6g

South Wales Echo (2018). Poor suffer from migrant onslaught; letters; Get in touch - tell us what you think, November 19. Available at: https://www.walesonline.co.uk/news/local-news/south-wales-echo-lettersmonday-15433234 (Accessed on 6th June 2019)

South Wales Echo (2019). EU scandal 'would surpass Windrush. January 21.

Spencer, I. R. (2002). British immigration policy since 1939: The making of multi-racial Britain. Routledge. Steimel, S.J. (2010). Refugees as people: The portrayal of refugees in American human-interest stories. Journal of Refugee Studies, 23(2), 219-237.

Sturge, G. (2019). Migration Statistics, Briefing Paper, Number CBP06077, House of Commons Library. Parliament UK. Available at: https://researchbriefings.files.parliament.uk/documents/.../SN06077.pdf (Accessed: 11 August 2019).

Tajfel, H., \& Turner, J. C. (1979). An integrative theory of intergroup conflict. In W. G. Austin, \& S. Worchel (Eds.), The social psychology of intergroup relations (pp. 33-37). Monterey, CA: Brooks/Cole. 
The Electoral Commission (2016). EU referendum results. [online] Available at: https://www.electoralcommission.org.uk/who-we-are-and-what-we-do/elections-and-referendums/past-elections-andreferendums/eu-referendum/results-and-turnout-eu-referendum [Accessed 12 July. 2019].

Threadgold, T. (2009). The Media and Migration in the United Kingdom, 1999 to 2009. Paper commissioned for the meeting "Public Opinion, Media Coverage, and Migration," May. Bellagio: Transatlantic Migration Council, Migration Policy Institute

Tuli, S. (2019). Migrants want to live in the big cities, just like the rest of us. The Conversation. Available at: https://theconversation.com/migrants-want-to-live-in-the-big-cities-just-like-the-rest-of-us-113911 (Accessed on 29th April 2019)

UK Border Agency (UKBA) (2011a). Migration Permanent Limit (Tier 1 and Tier 2 of the Points-Based System): Impact Assessment. London: Home Office.

UK Border Agency (UKBA) (2011b). Reform of the Points-Based Student Immigration System: Impact Assessment. London: Home Office.

Valentino, N. A., \& Nardis, Y. (2013). Political communication: Form and consequence of the information environment. In L. Huddy, D. O. Sears, \& J. S. Levy (Eds.), The Oxford handbook of political psychology (p. 559-590). Oxford University Press.

Van Gorp, B. (2005). Where is the frame? Victims and intruders in the Belgian press coverage of the asylum issue. European Journal of Communication, 20, 485-508.

Vicol, D.O., \& Allen, W. (2014). Bulgarians and Romanians in the British National Press, 1 December 2012-1 December 2013.Oxford: COMPAS, University of Oxford. Available at: http://migrationobservatory.ox.ac.uk/wp-content/uploads/2016/04/Report-Bulgarians_Romanians_Press_0.pdf(Accessed on 12 February 2019)

Walter, S. (2019). Better off without You? How the British Media Portrayed EU Citizens in Brexit News, International Journal of Press/Politics, SAGE Publications Inc. doi.org/10.1177/1940161218821509

YouGov (2015). YouGov/The Times Survey Results, YouGov online archive. Available at: https://d25d2506 sfb94s.cloudfront.net/cumulus_uploads/document/pw2zwai9dn/Times_Results_151218-Website.pdf [Accessed 10 May 2019]. 